\title{
Zastosowanie testu aktywacji bazofilów w diagnostyce nadwrażliwości na kwas acetylosalicylowy
}

\author{
Application of basophil activation test in diagnosing aspirin hypersensitivity \\ Praca nie była finansowana
}

\begin{abstract}
In the face of increasing prevalence of hypersensitivity reactions, introduction of effective, reliable and safe methods plays a crucial role in their diagnosing. Among the currently available laboratory (in vitro) methods is basophil activation test (BAT). It is a flow- cytometry based assay that allows to identificate in the blood sample basophils and additionally to asses the degree of cell activation after exposure to an antigen. The most common superficial identification markers are CD63 and CD203c, which increase in number after activation. Basophil actvation test can be applied to confirm diagnosis of allergy to Hymenoptera venoms, food, pollens and hypersensitivity to drugs. The aim of present paper is to present theoretical methods of this test as well as its pros and cons. We focus also on presentation of clinical case where BAT seemed to be a necessary addition to a routine diagnostic pathway. We present a case of identification of the culprit drug which caused an anaphylactic reaction
\end{abstract}

Key words: basophil activation test, BAT, hypersensitivity, NSAIDs, ASA

Pneumonol. Alergol. Pol. 2015; 83: 66-73

\section{Streszczenie}

W obliczu coraz powszechniej występujących reakcji nadwrażliwości niezwykle istotna jest skuteczna, wiarygodna, a przy tym bezpieczna dla chorego diagnostyka. Wśród aktualnie dostępnych metod laboratoryjnych znajduje się test aktywacji bazofilów (BAT). Badanie to, wykorzystujące cytometr przepływowy, umożliwia oznaczenie w pobranej próbce krwi bazofilów i jednocześnie ocenę stopnia ich aktywacji po ekspozycji na antygen. Do analizy tej najczęściej stosuje się markery powierzchniowe CD203c oraz CD63, które ulegają ekspresji po stymulacji komórki antygenem. Test aktywacji bazofilów wykorzystuje się do oceny alergii na jady owadów błonkoskrzydłych, pokarmy, pyłki roślin oraz nadwrażliwości na leki. Niniejszy artykuł przybliża podstawy teoretyczne wykonania badania oraz przedstawia zalety i wady tej metody diagnostycznej. Skupia się również na prezentacji przypadku z codziennej praktyki klinicznej, w którym BAT wykorzystano do uzupełnienia diagnostyki alergologicznej. Zaprezentowano przykład chorej z podejrzeniem nadwrażliwości na antybiotyk i niesteroidowy lek przeciwzapalny.

Słowa kluczowe: test aktywacji bazofilów, BAT, nadwrażliwość, kwas acetylosalicylowy, ASA

Pneumonol. Alergol. Pol. 2015; 83: 66-73

Address for correspondence: lek. Marika Gawinowska, Klinika Alergologii i Pneumonologii Uniwersyteckie Centrum Kliniczne ul. Dębinki 7, 80-952 Gdańsk 


\section{Wstęp}

Liczba osób cierpiących na choroby alergiczne w Europie szacowana jest na około $60 \mathrm{mln}$ [1]. W wielu krajach, w tym w Polsce, częstość tych chorób wciąż wzrasta. W związku z tym istotne jest wdrażanie do codziennej praktyki czułych, swoistych i bezpiecznych metod diagnostycznych umożliwiających szybkie rozpoznanie choroby i włączenie właściwej terapii. Podstawą diagnostyki chorób alergicznych są: dokładnie zebrany wywiad i badanie przedmiotowe umożliwiające zazwyczaj sformułowanie wstępnego rozpoznania, które następnie jest weryfikowane za pomocą badań dodatkowych. Podstawowy zakres badań przy podejrzeniu reakcji IgE-zależnej obejmuje punktowe testy skórne (PTS) oraz potwierdzenie obecności swoistych IgE. W przypadku podejrzenia alergii pokarmowej bądź nadwrażliwości o mechanizmie nieimmunologicznym „złotym standardem" jest natomiast wykonanie próby prowokacji kontrolowanej placebo. Stosunkowo nowym badaniem, które poszerza panel dostępnych procedur diagnostycznych, jest test aktywacji bazofilów (BAT, basophil activation test). Niniejsza praca ma za zadanie przybliżyć podstawy teoretyczne badania, zalety i wady tej procedury oraz jej przydatność w uzupełnieniu diagnostyki nadwrażliwości na niesteroidowe leki przeciwzapalne (NLPZ).

\section{Podstawy teoretyczne badania}

Bazofile, czyli granulocyty zasadochłonne są, obok komórek tucznych, głównymi komórkami efektorowymi reakcji alergicznej. Fizjologicznie ich bezwzględna liczba we krwi zawiera się w przedziale $10-300 / \mu \mathrm{l}$, co stanowi poniżej 1\% krążących leukocytów. Choć stanowią jedną z najmniej licznie reprezentowanych subpopulacji leukocytów obecnych we krwi obwodowej, ich rola w patofizjologii reakcji nadwrażliwości jest istotna. Po stymulacji receptorów o wysokim powinowactwie do IgE (FceRI) obecnych na powierzchni komórki przez przeciwciała IgE związane $\mathrm{z}$ alergenem dochodzi do mos tkowania receptorów i pobudzenia komórki. Efektem są zmiany w strukturze błony komórkowej towarzyszące procesowi degranulacji i uwolnieniu zawartych w ziarnistościach mediatorów reakcji zapalnej, w tym histaminy. Do degranulacji bazofilów może dojść również na skutek działania nieswoistych czynników. W tych reakcjach nie pośredniczą przeciwciała IgE. W publikacjach z lat 80. XX wieku zwrócono uwagę na możliwość wykorzystania bazofilów w diagnostyce alergologicznej [2, 3]. Prowadzone wówczas badania opierały się na pomiarze uwalnianych przez nie mediatorów - histaminy, tryptazy, sulfidoleukotrienów, granzymów. Pierwsze doniesienia na temat testu aktywacji bazofilów z wykorzystaniem markerów powierzchniowych pojawiły się w latach 90. XX wieku. Knol i wsp. opisali wówczas metodę oceny aktywacji bazofila po stymulacji przeciwciałem anty-IgE poprzez oznaczenie białka powierzchniowego CD63 [4]. Antygen ten oznaczono na powierzchni komórki za pomocą przeciwciał monoklonalnych znakowanych fluorochromem. Następnie metodą cytometrii przepływowej rozdzielano komórki znajdujące się w badanej próbce krwi na poszczególne subpopulacje, uwzględniając ich cechy morfologiczne (ziarnistość i wielkość) oraz obecność na powierzchni określonych antygenów. Aktualnie w testach cytometrycznych do wyodrębnienia omawianej populacji stosuje się antygeny CCR3 i CRTH2, ponadto celem odróżnienia od limfocytów wprowadza się bramkowanie negatywne CD3. W diagnostyce alergologicznej BAT z wykorzystaniem cytometrii przepływowej zastosował jako jeden z pierwszych zespół Sainte-Laudy [5].

Obecnie w teście aktywacji bazofilów wykorzystuje się dwie grupy markerów powierzchniowych: umożliwiające wyselekcjonowanie populacji bazofilów spośród różnych typów komórek (omówione powyżej) oraz określające stopień aktywacji komórki.

Powszechnie stosuje się dwa markery CD63 lub CD203c. CD63 strukturalnie jest błonowym białkiem związanym z lizozymem (LAMP-3, lysosyme associated membrane protein) zakotwiczonym w błonie ziarnistości zawierających histaminę. Dopiero po aktywacji bazofila dochodzi do połączenia ziarnistości egzocytarnych z błoną komórkową i tym samym ekspresji antygenu na powierzchni komórki [6]. Początkowo sądzono, że pomiar stopnia ekspresji CD63 jest równorzędny z ilością uwalnianej przez bazofile histaminy [4]. Wyniki późniejszych badań wykazały jednak, że możliwa jest ekspresja tego antygenu bez uwalniania mediatorów. Białko CD63 występuje również na innych komórkach: mastocytach, makrofagach oraz płytkach krwi, stąd do różnicowania bazofilów konieczne jest oznaczanie kilku antygenów swoistych dla tych komórek.

Drugim markerem służącym ocenie aktywacji jest CD203. Jest to neuronalny powierzchniowy antygen różnicowania neuronów, należący do rodziny pirofosfataz/fosfodiesteraz, który w niewielkiej ilości wykrywa się na powierzchni błony 
komórkowej bazofila w spoczynku [7]. Ekspresja tego białka znacznie wzrasta pod wpływem stymulacji receptorów dla fragmentów Fc IgE na powierzchni bazofila [8]. Marker ten, w odróżnieniu od CD63, jest swoisty dla bazofilów. W ostatnich latach oprócz dwóch wymienionych wyżej antygenów wykryto nowe markery aktywacji bazofilów - CD13, CD107a oraz CD164 [9]. Nie są one jednak powszechnie wykorzystywane, przez co BAT opiera się najczęściej na ocenie CD63 i CD203c.

Określono również dynamikę zmian ekspresji poszczególnych markerów aktywacji bazofilów. $\mathrm{Na}$ tej podstawie wyszczególniono markery szybko pojawiające się na powierzchni bazofila (grupa „fast responders”, w skład której wchodzą oprócz CD203 również CD13 i CD164). Antygeny te pojawiają się na powierzchni pobudzonego bazofila 15 minut po stymulacji antygenowej. $\mathrm{Z}$ kolei druga grupa markerów, obejmująca cząsteczki CD63 oraz CD107a, wymaga trzykrotnie dłuższego czasu do ekspresji powierzchniowej. Posłużyło to do postawienia tezy o odmiennych mechanizmach prowadzących od aktywacji do ekspresji i degranulacji komórek [9]. Warto jednak podkreślić, że w innym badaniu ekspresję powierzchniową wystarczającą do uzyskania wiarygodnych wyników obu markerów - CD63 i CD203c zanotowano po 20-30 minutach inkubacji [10].

\section{Antygeny powierzchniowe aktywacji CD63 i CD203c}

Próba porównania czułości i swoistości najpowszechniej stosowanych antygenów - CD63 i CD203c nie dała jednoznacznej odpowiedzi, który z nich jest lepszym markerem aktywacji bazofilów. Wyniki licznych badań i publikacje pokazują, że w zależności od przyjętego schematu badania, zasad wykonania, badanego alergenu i mechanizmu reakcji występują istotne różnice w uzyskanych wynikach. W badaniu porównującym stopień aktywacji bazofilów przy użyciu CD63 lub CD203c wśród pacjentów z alergią na jady owadów błonkoskrzydłych uzyskano nieznacznie wyższą czułość w przypadku CD203c niż CD63 - odpowiednio 85\% v. 79,7\% (p = 0,405 ) [10]. Z kolei w przypadku oceny wpływu kwasu acetylosalicylowego (ASA, acetylosalicylic acid) na ekspresję markerów aktywacji wykazano, że CD63 jest 5 razy bardziej czuły niż CD203c $(\mathrm{p}<0,0001)[11]$.

Marker CD203c występuje w niewielkiej ilości nawet na powierzchni niepobudzonych komórek, po aktywacji wykrywany jest na wszyst- kich bazofilach [12]. Marker CD63 występuje wyłącznie na powierzchni pobudzonych bazofilów, jednak ulega ekspresji tylko na części komórek, pomimo obecności na błonach wewnątrzkomórkowych. W Laboratorium Immunologii Klinicznej Transplantacyjnej i Hematologii Uniwersyteckiego Centrum Klinicznego Gdańskiego Uniwersytetu Medycznego ocenia się ekspresję obu antygenów aktywacji - CD63 i CD203 za pomocą przeciwciał połączonych z tym samym fluorochromem.

Przy ocenie wyniku testu aktywacji bazofilów należy wziąć pod uwagę występowanie chorych, u których bazofile nie są aktywowane i nie wydzielają mediatorów po stymulacji FceRI. Populację tę określa się mianem „niewydzielaczy” (non-responder). Pomimo prawidłowej ekspresji receptorów FcєRI na powierzchni komórki po stymulacji nie dochodzi w tej grupie do wydzielania histaminy lub jej ilość jest minimalna (wg Kumara i wsp. < 5\% histaminy [13]). Przyczyny tego zjawiska upatruje się w braku kinazy tyrozynowej Syk i zmniejszonej ilości kinazy Lyn, które odgrywają kluczową rolę w przekazywaniu sygnału z aktywowanego receptora FceRI do wnętrza komórki [14]. Udowodniono, że poziom mRNA kinazy tyrozynowej Syk w komórkach „wydzielaczy” i „niewydzielaczy” jest porównywalny, a przyczyną zmniejszonej ilości produktu translacji może być nadmierna jego degradacja przez proteasomy [15]. Bazofile „niewydzielaczy” reagują natomiast na stymulację nie związaną z IgE [13]. Kwestia oceny populacji niewydzielaczy jest zatem niezwykle istotna w diagnostyce alergologicznej mechanizmu IgE-zależnego.

Populację „niewydzielaczy”, u których na skutek zaburzonego szlaku sygnału wewnątrzkomórkowego nie dochodzi do ekspresji antygenu CD63 i CD203c na powierzchni bazofilów, szacuje się na około 5-10\% populacji ogólnej [16]. W badaniu Lama i wsp., w którym porównywano populację osób zdrowych i chorych na astmę, określono, że $28 \%$ populacji kontrolnej stanowią osoby o fenotypie „non-responder”, a wśród chorych odsetek ten jest znacznie mniejszy i wynosi 13\% [17]. Brak odpowiedzi na stymulację alergenową w grupie „non-responder” może być zatem źródłem częstych wyników fałszywie ujemnych [18]. W celu weryfikacji populacji „niewydzielaczy” w teście BAT stosuje się dwie kontrole dodatnie - ocenie podlega stopień aktywacji bazofilów po dodaniu przeciwciał anty FCeR oraz fMLP. Ponadto, opisano wpływ zewnątrzkomórkowego stężenia $\mathrm{Ca}^{+2}$ na ekspresję markerów powierzchniowych. Wysokie stężenie zwiększa ekspresję, 
Tabela 1. Zalety i wady testu aktywacji bazofilów (BAT) w porównaniu z innymi metodami diagnostycznymi w praktyce klinicznej

Table 1. Advantages and disadvantages of basophil activation test (BAT) in comparison to other diagnostic methods in clinical practise

\begin{tabular}{|c|c|c|c|c|}
\hline & BAT & $\begin{array}{c}\text { Testy } \\
\text { skórne }\end{array}$ & $\operatorname{slg} E$ & Próba prowokacji \\
\hline $\begin{array}{l}\text { Konieczne szybkie wykonanie testu od momentu pobrania krwi } \\
\text { (ograniczona możliwość transportu materiału) }\end{array}$ & + & nie dotyczy & - & nie dotyczy \\
\hline Wysoka cena & ++ & - & + & - \\
\hline Konieczność odstawienia leków przeciwhistaminowych & - & + & - & + \\
\hline Ryzyko anafilaksji & - & + & - & + \\
\hline Komfort psychiczny chorego & + & $+/-$ & + & - \\
\hline Wymagana hospitalizacja chorego & - & - & - & + \\
\hline Możliwość jednoczasowego oznaczania wpływu kilku alergenów & + & + & + & - \\
\hline Wymagany doświadczony personel laboratorium/oddziału & + & + & + & + \\
\hline Ograniczona dostępność badania - wymagany kosztowny sprzęt laboratoryjny & ++ & - & + & - \\
\hline Różnicowanie reakcji krzyżowych i rzeczywistego poliwalentnego uczulenia & + & - & $+/-$ & - \\
\hline Zróżnicowana czułość testu w zależności od badanego czynnika & + & + & - & (brak danych) \\
\hline Ryzyko wyników fałszywie ujemnych & $\begin{array}{l}\text { Grupa "non- } \\
\text {-responder" }\end{array}$ & $\begin{array}{l}\text { Wpływ } \\
\text { leków }\end{array}$ & - & wpływ leków \\
\hline
\end{tabular}

ale zjawisko to dotyczy markeru CD64, a nie CD203c. W przypadku niskiego poziomu wapnia możemy mieć do czynienia ze zjawiskiem „fałszywego" non-responder [19]. Należy zawsze brać pod uwagę rezultat powyższych analiz przy ostatecznej ocenie wyników testu aktywacji bazofilów.

\section{Test aktywacji bazofilów a testy skórne, próby prowokacji}

Test aktywacji bazofilów jest badaniem prowadzonym in vitro, przez co chory nie jest narażony na kontakt z alergenem. Dzięki temu unika się ryzyka reakcji anafilaktycznych, które mogą występować w czasie prowadzenia badań in vivo testów skórnych czy prób prowokacyjnych. Sytuacje te nie są częste - ogólne ryzyko reakcji anafilaktycznej w trakcie testów skórnych wynosi $0,02 \%$; większym ryzykiem obarczona jest diagnostyka w kierunku alergii na penicyliny (1\%) i jady owadów (1,4\%) [20]. Z kolei reakcje anafilaktyczne w trakcie prób prowokacji są sporadyczne z uwagi na przestrzeganie obostrzeń i zaleceń prób, każda diagnostyka zakończona wynikiem pozytywnym niesie jednak ze sobą potencjalne ryzyko rozwoju z niewielkich objawów nadwrażliwości reakcji anafilaktycznej. Dla chorych pobranie niewielkiej próbki krwi jest mniej obciążające niż związana z dużym stresem próba prowokacji. Test aktywacji bazofilów zapewnia obiektywny wynik, bez ryzyka efektu placebo. Należy jednak pamiętać o wspomnianej możliwości uzyskania wyników fałszywie ujemnych.

Przygotowanie materiału i wykonanie niezbędnych oznaczeń umożliwia uzyskanie wyników BAT w ciągu 2 godzin. Jest to duża zaleta tej metody diagnostycznej w porównaniu z czasochłonnymi próbami prowokacyjnymi. Ograniczeniem jest natomiast konieczność przeprowadzenia oznaczeń w świeżo pobranym materiale, co istotnie zmniejsza możliwość jego transportu do odległego laboratorium. Upływający czas wpływa niekorzystnie na żywotność zawartych w próbce bazofilów. Badanie po $48 \mathrm{~h}$ przechowania w temp. $4^{\circ} \mathrm{C}$ powoduje zmniejszenie maksymalnej ekspresji powierzchniowej o 56,1\% [10]. Zalecane jest więc przeprowadzenie testu w jak najkrótszym czasie, najlepiej do 24 godzin od pobrania materiału.

Istotnym ograniczeniem testów skórnych oraz prób prowokacji jest konieczność odstawienia leków mogących wpłynąć na ich wyniki. Przed wykonaniem PTS pacjent powinien zaprzestać przyjmowania leków przeciwhistaminowych, glikokortykosteroidów doustnych w dawce większej niż ekwiwalent 10 mg prednizonu czy stosowania na skórę przedramion miejscowo działających steroidów i inhibitorów kalcyneuryny [21]. Do próby prowokacji aspirynowej konieczne jest z kolei odstawienie oprócz leków przeciwhistaminowych, również wziewnych beta agonistów, leków przeciwcholinergicznych, teofiliny oraz leku przeciwleukotrienowego [22]. Odpowiednie przygotowanie pacjenta pod wzglę- 
Tabela 2. Porównanie czułości i swoistości testu aktywacji bazofilów na przykładzie wybranych reakcji lgE-zależnych oraz IgE-niezależnych

Table 2. Comparison of sensitivity and specificity of basophil activation test in IgE-mediated reaction and non-IgE mediated reaction

\begin{tabular}{lcccc}
\hline \multicolumn{1}{c}{ Mechanizm reakcji } & Badany czynnik & Czułość (\%) & Swoistość (\%) & Piśmiennictwo \\
\hline \multirow{3}{*}{ IgE-zależny } & Jad owadów błonkoskrzydłych & $80-92$ & 80 & {$[10,24]$} \\
& Mix pyłków 6 traw & $75-92$ & 100 & {$[23]$} \\
Nie-lgE zależny & Roztocza kurzu (D. pteronyssinus) & $88-94$ & 100 & {$[23]$} \\
\hline
\end{tabular}

dem modyfikacji leczenia jest zatem wymagane do prawidłowego przeprowadzenia diagnostyki alergologicznej. W pewnych przypadkach pod wpływem zmiany terapii choroby przewlekłej dochodzi do jej zaostrzenia (np. po odstawieniu leków przeciwhistaminowych w przewlekłej pokrzywce), co może uniemożliwić przeprowadzenie diagnostyki.

Wyniki badań Wolańczyk-Mędrala wykazały, że leki przeciwhistaminowe nie mają wpływu na wyniki testów aktywacji bazofilów. Test aktywacji bazofilów wykonywano w materiale pobranym przed i 2 godziny po przyjęciu przez badanych cetyryzyny (w dawce $10 \mathrm{mg}$ ) nie stwierdzając istotnych różnic w ilości uzyskanych wyników dodatnich, choć zmniejszył się stopień aktywacji bazofilów w drugim etapie badania [23]. Podobne wyniki uzyskała Sturm i wsp. w badaniu z zastosowaniem desloratadyny w podwójnej dobowej dawce $(10 \mathrm{mg})$. W tym badaniu podjęto również próbę oceny wpływu glikokortykosteroidów na aktywację bazofilów. Wpływ prednizolonu oceniano wyłącznie in vitro, podając go do pobranej próbki krwi w stężeniu 50, 500 i $2500 \mathrm{ug} / \mathrm{ml}$ i oceniając aktywację bazofilów po stymulacji przeciwciałem anty IgE. Nie obserwowano wpływu prednizolonu na obniżenie ekspresji CD203c, jakkolwiek nie potwierdza to jednoznacznie braku wpływu ogólnoustrojowej steroidoterapii na wyniki BAT [10]. Należy podkreślić, że podstawą wykonania testu BAT jest wyizolowane bazofilów z próbki krwi obwodowej. Każdy stan powodujący zmniejszenie ilości krążących bazofilów ograniczy również możliwość przeprowadzenia badania oraz zmniejszy wiarygodność uzyskanego wyniku.

Zaletami testu aktywacji bazofilów są zatem jego nieinwazyjność i bezpieczeństwo, natomiast istotnymi ograniczeniami - wysokie wymagania co do sprzętu laboratoryjnego, konieczność wykonania badania w świeżo pobranym materiale i wysoki koszt (tab. 1). Analizując aspekt ekonomiczny diagnostyki nadwrażliwości na aspirynę, należy wziąć pod uwagę fakt, że próba doustnej prowokacji wymaga minimum dwudniowej hospitalizacji chorego. Wiąże się to z nakładami finansowymi ze strony płatnika oraz kosztami ponoszonymi przez chorego (niemożność pełnienia ról społecznych i zawodowych). Test aktywacji bazofilów pomimo wysokiego kosztu jednostkowego pozbawiony jest powyższych obciążeń.

Należy podkreślić, że test aktywacji bazofilów ma ugruntowaną pozycję w diagnostyce nadwrażliwowści IgE-zależnej (jak jady owadów błonkoskrzydłych, pyłki, pokarmy, lateks, niektóre leki) ze względu na dobrze poznane mechanizmy reakcji. $\mathrm{W}$ tabeli 2 przedstawiono porównanie swoistości i czułości testu aktywacji bazofilów na przykładzie reakcji IgE-zależnych i IgE-niezależnej.

$\mathrm{W}$ diagnostyce in vitro nadwrażliwości na kwas acetylosalicylowy zaproponowano poza testem aktywacji bazofilów również inne badania. Wśród nich jest test oparty na ocenie uwalniania leukotrienów cysteinylowych z leukocytów krwi obwodowej po stymulacji aspiryną (CAST, cellular antigen stimulation test). Uzyskane wyniki nie są jednak zadowalające - $\mathrm{w}$ jednym z badań oceniona czułość i specyficzność wyniosły odpowiednio $25 \%$ i $92 \%$ [25]. Ciekawe rozwiązanie to połączenie dwóch metod - cytometrii przepływowej z oceną uwalniania leukotrienów, które zwiększa czułość metody, ale kosztem specyficzności [26]. Kolejna metoda diagnostyki - polega na ocenie wytwarzania kwasu 15-hydroksyeikozatetraenowego (15-HETE) z leukocytów (ASPITest, Aspirin Sensitive Patient Identification Test), w którym oceniona czułość i swoistość wynoszą $83 \%$ oraz $82 \%$ [27]. Jak do tej pory nie ma jednak dostateczenej liczby doniesien, w tym z badań wśród licznej grupy pacjentów poświęconych tej metodzie. Wydaje się, że BAT pomimo swojej niedoskonałości i aspektów technicznych, które należy wziąć pod uwagę przy ocenie wyniku, jest $\mathrm{w}$ diagnostyce in vitro nadwrażliowści na aspirynę badaniem godnym uwagi. 


\section{Zastosowanie testu aktywacji bazofilów w diagnostyce nadwrażliwości na kwas acetylosalicylowy}

Niesteroidowe leki przeciwzapalne (NLPZ) pod względem częstości wywoływania reakcji nadwrażliwości, w zależności od badanej populacji zajmują pierwsze [28] bądź drugie miejsce (po antybiotykach) [29]. Częstość nadwrażliwości na NLPZ można wytłumaczyć między innymi łatwością dostępu do tej grupy leków, samodzielnym ich przyjmowaniem bez nadzoru lekarskiego oraz dużym zakresem wskazań do ich zastosowania. Ocenia się, że 0,6\% populacji ogólnej wykazuje nadwrażliwość na aspirynę [30]. Zaburzenie to jest zdecydowanie częstsze u chorych na astmę. Według badania opartego na dokładnym wywiadzie przeprowadzonym w Polsce, u 4,3\% dorosłych chorych na astmę rozpoznano nadwrażliwość na aspirynę. Natomiast na podstawie próby prowokacji aspirynowej u astmatyków częstość szacuje się na 8-20\%, co może świadczyć o tym, że duża część chorych nie łączy objawów nadwrażliwości z czynnikiem sprawczym [31]. Szczególną grupę stanowią chorzy na astmę z towarzyszącym przewlekłym zapaleniem błony śluzowej nosa i zatok, wśród których co 4 osoba wykazuje nadwrażliwość na ASA (25,6\%) [32].

\section{Przykład z praktyki klinicznej}

Chora, 52-letnia, bez istotnych obciążeń internistycznych, została przyjęta do kliniki w celu rozpoznania nadwrażliwości na leki. W wywiadzie około rok wcześniej w trakcie terapii ambulatoryjnej zakażenia dolnych dróg oddechowych wystąpiła u chorej utrata przytomności. Udzielił jej pomocy zespół pogotowia ratunkowego. Z dokumentacji medycznej wynika, że stwierdzono cechy wstrząsu - obniżenie ciśnienia tętniczego do wartości 80/40 mm Hg, tachykardię 120/min oraz cechy centralizacji krążenia. Po zastosowaniu intensywnej płynoterapii, podaniu hydrokortyzonu oraz leków przeciwhistaminowych uzyskano stabilizację stanu pacjentki. Wykluczono przyczyny kardiologiczne mogące mieć wpływ na stan chorej. W związku z tym, że chora przyjmowała w tym czasie antybiotyk - amoksycylinę, wysunięto podejrzenie wstrząsu anafilaktycznego spowodowanego alergią na aminopenicyliny. Po szczegółowym zebraniu wywiadu okazało się, że oprócz antybiotyku chora przyjmowała w czasie choroby lek przeciwgorączkowy - ibuprofen. W związku z tym przeprowadzono diagnostykę dwukierunkowo z uwzględnieniem amoksycyliny i NLPZ. W warunkach szpitalnych wyko- nano punktowe testy skórne i testy śródskórne $\mathrm{z}$ antybiotykami - amoksycyliną oraz, w celu wykluczenia alergii krzyżowej, z cefalosporyną (cefuroksym). Testy skórne wykonano zgodnie z standardami Polskiego Towarzystwa Alergologicznego [20] i w obu przypadkach uzyskano wyniki negatywne. Następnie przeprowadzono kontrolowaną placebo próbę prowokacji amoksycyliną monitorowaną klinicznie oraz spirometrycznie. Po podaniu sumarycznie największej dawki dobowej stosowanej w terapii (2 g) nie stwierdzono cech nadwrażliwości. W związku $\mathrm{z}$ tym kontynuowano diagnostykę $\mathrm{w}$ kierunku nadwrażliwości na NLPZ. Ze względu na duże ryzyko wystąpienia ponownej reakcji anafilaktycznej rozważono wykonanie diagnostyki in vitro. Pobrano krew chorej w celu wykonania BAT z kwasem acetylosalicylowym. Aktywacje bazofilów z użyciem markera CD63 oceniono na $22 \%$, przy wartości $10 \%$ przyjętej w laboratorium Uniwersyteckiego Centrum Klinicznego w Gdańsku za punkt odcięcia. Po całościowej analizie wywiadu oraz uzyskanych wyników badań ibuprofen uznano za czynnik sprawczy wstrząsu anafilaktycznego. W związku z tym zalecono chorej nieprzyjmowanie leków z grupy NLPZ, a w razie gorączki czy dolegliwości bólowych zalecono stosowanie paracetamolu lub tramadolu. Od tego czasu, w rocznej obserwacji nie stwierdzono objawów nadwrażliwości u tej chorej.

Podkreśla się kilka mechanizmów wczesnych reakcji po przyjęciu NLPZ. W reakcji IgE-zależnej objawy występują po jednej, konkretnej substancji należącej do grupy NLPZ. Zdecydowanie częściej natomiast występuje mechanizm IgE-niezależny (krzyżowa nietolerancja), u którego podłoża leży blokowanie enzymu szlaku kwasu arachidonowego - cyklooksygenazy (COX) [33]. Istnieją dwie izoformy tego enzymu: COX-1 konstytutywnie wytwarzana $w$ obrębie m.in śródbłonka naczyń krwionośnych czy nabłonka przewodu pokarmowego oraz COX-2, której produkcja indukowana jest w komórkach z toczącym się stanem zapalnym. Postuluje się, że u podłoża reakcji nadwrażliwości leży blokowanie fizjologicznej COX-1; z tego powodu leki będące inhibitorami obu izoform częściej wywołują reakcje nadwrażliwości niż leki silniej blokujące COX-2. Nadwrażliwość spowodowana reakcją krzyżową związaną z blokowaniem COX-1 oceniana jest na $76 \%$ przypadków wobec $24 \%$ reakcji występujących tylko po pojedynczym leku [34].

W diagnostyce nadwrażliwości na ASA i inne leki z grupy NLPZ aktualne postępowanie diagno- 
styczne polega na zebraniu dokładnego wywiadu pod kątem reakcji po przyjęciu leków z tej grupy oraz wykonaniu próby prowokacji ASA. W zależności od drogi podania wyróżnia się doustną, donosową oraz wziewną próbę prowokacji. Czułość wymienionych prób wynosi w kolejności: 89\%, $77-90 \%$ oraz $80-86,7 \%$, a za ,złoty standard” diagnostyczny przyjęto próbę prowokacji doustnej [35]. Ze względu na ryzyko reakcji anafilaktycznej w trakcie próby, niemożność odstawienia leków przyjmowanych przewlekle przez chorych, niespecyficzne objawy zgłaszane przez pacjentów niemożliwe do obiektywnej oceny w badaniu przedmiotowym czy spirometrycznym lub też zdarzające się zakończenie badania na etapie placebo, zachęcające wydaje się użycie do diagnostyki BAT.

Na podstawie badań szacuje się, że czułość BAT w ocenie nadwrażliwości na ASA przy użyciu markera CD63 wynosi 37-61\%, a swoistość 90\% [11, 28]. Z kolei wartość predykcyjną dodatnią oceniono na $92 \%$, a wartość predykcyjną negatywną na 59\% [28]. Analiza szerszego zakresu badań potwierdza niejednoznaczne, rozbieżne wyniki uzyskanych wyników BAT z ASA (co może wynikać z doboru pacjentów, metodyki wykonywanych testów, nieimmunologicznego charakteru reakcji) [36]. Są to stosunkowo niskie wartości i świadczą o niedoskonałości metody diagnostycznej - próba prowokacji okazuje się bardziej wiarygodna. Pokazuje to, że BAT wydaje się bardziej użyteczny w potwierdzaniu choroby niż jej wykluczeniu. Może też być wykorzystywany jako wstępny test przed próbą prowokacji, zwłaszcza u chorych, u których doszło do reakcji anafilaktycznej. Wynik negatywny wymagałby potwierdzenia poprzez przeprowadzenie próby prowokacji.

Gdy poddano szczegółowej analizie manifestowane przez chorych objawy, okazało się, że w grupie wykazującej cięższe reakcje (jak obrzęk krtani, duszność, zaburzenia jelitowe) wyniki dodatnie były częstsze niż w grupie z objawami tylko ze strony skóry czy grupy kontrolnej. Dodatnią wartość predykcyjną oceniono na $64 \%$ (negatywna wartość predykcyjna - 79\%) [28].

Potwierdzenie nadwrażliwości na ASA współistniejącej z chorobą dróg oddechowych zaostrzaną przez aspirynę (AERD, aspirin-exacerbated respiratory disease) lub przewlekłą pokrzywką ma istotne implikacje kliniczne. Daje możliwość zastosowania dodatkowych metod terapeutycznych w postaci włączenia do terapii leków blokujących receptor dla leukotrienów montelukastu, zafirlukastu lub przeprowadzenia desensytyzacji aspiryną [37].

\section{Podsumowanie}

W związku z narastającą częstością występowania chorób alergicznych wskazane jest poszukiwanie i udoskonalanie nowych metod diagnostycznych. Test aktywacji bazofilów wydaje się obiecującą, innowacyjną metodą in vitro mogącą uzupełniać proces diagnostyczny, szczególnie w przypadkach wątpliwych, w których rutynowo stosowane metody nie przynoszą oczekiwanych odpowiedzi. Podkreśla się przydatność BAT w diagnostyce alergii o podłożu IgE-zależnym; należy zwrócić uwagę również na możliwość wykorzystania tego testu w diagnostyce nadwrażliwości o złożonym mechanizmie. Przykład przedstawiony w niniejszej pracy pokazuje możliwość jego wykorzystania w pracy klinicznej w ocenie nadwrażliwości na kwas acetylosalicylowy. Należy jednak podkreślić, że aktualnie obowiązujące standardy alergologiczne nie zalecają stosowania BAT rutynowo ze względu na niewystarczającą czułość, swoistość i powtarzalność wyników. Ostateczne miejsce BAT w procesie diagnostyki alergologicznej wymaga dalszych badań. W celu rozwoju i standaryzacji testu aktywacji bazofilów utworzono pod auspicjami Europejskiej Akademii Alergologii i Immunologii Klinicznej (EAACI) grupę EuroBAT.

\section{Konflikt interesów}

Autorzy nie zgłaszają konfliktu interesów.

\section{Piśmiennictwo}

1. Papadopoulos N.G., Agache I., Bavbek S. i wsp. Research needs in allergy: an EAACI position paper, in collaboration with EFA. Clin Transl Allergy 2012; 2: 21. doi: 10.1186/2045-7022-2-21.

2. Benveniste J. The human basophil degranulation test as an in vitro method for diagnosis of allergies. Clin. Allergy 1981; 11: 1-11.

3. Górski P., Grzegorczyk J., Rożniecki J. Test degranulacji bazofilów w diagnostyce alergicznej in vitro na przykładzie dychawicy pyłkowej. Pol. Tyg. Lek. 1984; 31: 1039-1040.

4. Knol E.F., Mul F.P., Jansen H., Calafat J., Roos D. Monitoring human basophil activation via CD63 monoclonal antibody 435. J. Allergy Clin. Immunol. 1991; 88: 328-338.

5. Sainte-Laudy J., Vallon C., Guerin J.C. Analysis of membrane expression of the CD63 human basophil activation marker. Applications to allergologic diagnosis. Allerg. Immunol. (Paris); 1994; 26: 211-214.

6. Potapińska O., Demkow U., Wąsik M. Cytometryczna ocena aktywacji bazofilów w diagnostyce chorób alergicznych. Pneumonol. Alergol. Pol. 2009; 77: 152-158.

7. Platz I.J., Binder M., Marxer A., Lischka G., Valent P., Bühring H.J. Hymenoptera - venom- induced upregulation of the basophil activation marker ecto- nucleotide pyrophosphatase/ phosphodiesterase 3 in sensitized individuals. Int. Arch. Allergy Immunol. 2001; 126: 335-342.

8. Boumiza R., Dabard A.L., Monneret G. The basophil activation test by flow cytometry: recent developments in clinical study, standardization and emerging perspectives. Clin. Mol. Allergy 2005; 3-9. 
9. Hennersdorf F., Florian S., Jakob A. i wsp. Identification of CD13, CD107a, and CD164 as novel basophil-activation markers and dissection of two response patterns in time kinetics of IgE-dependent upregulation. Cell. Res. 2005;15: 325-335.

10. Sturm E.M., Kranzelbinder B., Heinemann A., Groselj- Strele A., Aberer W., Sturm G.J. CD203c-based basophil activation test in allergy diagnosis: characteristics and differences to CD63 upregulation. Cytometry Part B 2010; 78: 308-318. doi: 10.1002/ cyto.b.20526.

11. Abuaf N., Rostane H., Barbara J. i wsp. Comparison of CD63 Upregulation Induced by NSAIDs on Basophils and Monocytes in Patients with NSAID Hypersensitivity. J. Allergy (Cairo) 2012, 2012: 580873. doi: 10.1155/2012/580873.

12. Chirumbolo S., Vella A., Ortolani R. i wsp. Differential response of human basophil activation markers: a multi-parameter flow cytometry approach. Clin. Mol. Allergy 2008;6:12-25. doi: 10.1186/1476-7961-6-12.

13. Kumar P., Singh B., Lal R., Rembhotkar G.W., Singh A.B. Association between reduced level of total serum IgE and FcepsilonRI expression non-releaser basophils. Immunobiology 2009;214: 377-383. doi: 10.1016/j.imbio.2008.09.008.

14. Kepley C.L., Youssef L., Andrews R.P., Wilson B.S., Oliver J.M. Syk deficiency in nonreleaser basophils. J. Allergy Clin. Immunol. 1999; 104: 279-284.

15. Youssef L.A., Wilson B.S., Oliver J.M. Proteasome-dependent regulation of Syk tyrosine kinase levels in human basophils. J. Allergy Clin. Immunol. 2002;110: 366-373.

16. Ebo D.G., Sainte-Laudy J., Bridts C.H. i wsp. Flow-assisted allergy diagnosis: current applications and future perspectives. Allergy 2006; 61: 1028-1039.

17. Lama A., Youssef L.A., Schuyler M. i wsp. Histamine release from the basophils of control and asthmatic subjects and a comparison of gene expression between "releaser" and "non-releaser" basophils. J. Immunol. 2007;178: 4584-4594.

18. Chełmińska M. Różnicowanie reakcji krzyżowych towarzyszących alergii na lateks - wybrane zagadnienia. Annales Academiae Medicae Gedanensis, 2010 (supl. 12).

19. De Weck A.L., Sanz M.L., Gamboa P.M. i wsp. Diagnostic tests based on human basophils: more potentials and perspectives than pitfalls. II. Technical issues. J. Investig. Allergol. Clin. Immunol. 2008; 18: 143-155.

20. Liccardi G., D’Amato G., Canonica G.W., Salzillo A., Piccolo A., Passalacqua G. Systemic reactions from skin testing: literature review. J. Investig. Allergol. Clin. Immunol. 2006; 16: 75-78.

21. Kruszewski J., Kowalski M. Standardy w alergologii. Część I wydanie II, Kraków 2010: 32-33, 94-98.

22. Niżankowska-Mogilnicka E., Bochenek G., Mastalerz L. i wsp. EAACI/GA2LEN guideline: aspirin provocation tests for diagnosis of aspirin hypersensitivity. Allergy 2007; 62: 1111-1118.

23. Wolańczyk-Medrala A., Gogolewski G., Liebhart J. i wsp. A new variant of the basophil activation test for allergen-induced basophil CD63 upregulation. The effect of cetirizine. J. Investig. Allergol. Clin. Immunol. 2009; 19: $465-473$.

24. Erdmann S.M., Sachs B., Kwiecień R. i wsp. The basophil activation test in wasp venom allergy: sensitivity, specificity and monitoring specific immunotherapy. Allergy 2004; 59: $1102-1129$.

25. Bavbek S., Dursun A.B., Birben E. i wsp. Cellular allergen stimulation test with acetylsalicylic acid-lysine is not a useful test to discriminate between asthmatic patients with and without acetylsalicylic acid sensitivity. Int. Arch. Allergy Immunol. 2009; 149: 58-64. doi: 10.1159/000176307.

26. Sanz M.L., Gamboa P., de Weck A.L. A new combined test with flowcytometric basophil activation and determination of sulfidoleukotrienes is useful for in vitro diagnosis of hypersensitivity to aspirin and other nonsteroidal anti-inflammatory drugs. Int. Arch. Allergy Immunol. 2005; 136: 58-72.

27. Kowalski M.L., Ptasinska A., Jedrzejczak M. i wsp. Aspirin-triggered 15-HETE generation in peripheral blood leukocytes is a specific and sensitive Aspirin-Sensitive Patients Identification Test (ASPITest). Allergy 2005; 60: 1139-1145.

28. Kim M.S., Young J.C. Flow cytometry-assisted basophil activation test as a safe diagnostic tool for aspirin/nsaid hypersenstivity. Allergy Asthma Immunol. Res. 2012; 4: 137-142. doi: 10.4168/aair.2012.4.3.137.

29. Gomes E.R., Demoly P. Epidemiology of hypersensitivity drug reactions. Curr. Opin. Allergy Clin. Immunol. 2005; 5: 309-316.

30. Kasper L., Sladek K., Duplaga M. i wsp. Prevalence of asthma with aspirin hypersensitivity in the adult population of Poland. Allergy 2003; 58: 1064-1066.

31. Szczeklik A., Niżankowska E., Duplaga M. Natural history of aspirin-induced asthma. Eur. Respir. J. 2000; 16: 432-436.

32. Kim J.E., Kountakis S.E. The prevalance of Samter's triad in patient undergoing functional endoscopic sinus surgery. Ear Nose Throat J. 2007; 86: 396-399.

33. Szczeklik A., Gryglewski R., Czerniawska-Mysik G. Relationship of inhibition of prostaglandin biosynthesis by analgesics to asthma attacks in aspirin- sensitive patients. Br. Med. J. 1975; 1: 67-69.

34. Dona I., Blanca-Lopez N., Cornejo-Garc'1a J.A. i wsp. Characteristics of subjects experiencing hypersensitivity to non-steroidal anti-inflammatory drugs: patterns of response. Experimental Allergy 2011; 41: 86-95. doi: 10.1111/j.13652222.2010.03651.x.

35. Kowalski M.L., Makowska J.S., Blanca M. i wsp. Hypersensitivity to nonsteroidal anti-inflammatory drugs (NSAIDs) - classification, diagnosis and management: review of the EAACI/ ENDA(\#) and GA2LEN/HANNA*. Allergy 2011; 66: 818-829. doi: 10.1111/j.1398-9995.2011.02557.x.

36. Song W.J., Chang Y.S. Recent applications of basophil activation tests in the diagnosis of drug hypersensitivity. Asia Pac Allergy_2013; 3: 266-280. doi: 10.5415/apallergy.2013.3.4.266.

37. Specjalski K., Chełmińska M. Rozpoznanie i leczenie astmy aspirynowej. Pol. Arch. Med. Wewn. 2006; 115: 381-385. 